Article

\title{
When Ads Become Invisible: Minors' Advertising Literacy While Using Mobile Phones
}

\author{
Beatriz Feijoo ${ }^{1, *}$ and Charo Sádaba ${ }^{2}$ \\ ${ }^{1}$ Communication Department, International University of La Rioja, Spain \\ ${ }^{2}$ Marketing and Media Management Department, University of Navarra, Spain \\ *Corresponding author (beatriz.feijoo@unir.net)
}

Submitted: 21 July 2021 | Accepted: 29 September 2021 | Published: 29 March 2022

\begin{abstract}
It has been traditionally estimated that children begin to understand the persuasive intent of advertising at about the age of 8 which is when they acquire the skills of adult consumers. The ability to identify and interpret the persuasive content that minors are exposed to via mobile phones was analyzed through semi-structured interviews of children aged 10 to 14 years along with their parents in 20 households. Although minors seem to be able to recognize the persuasive intent of advertising, this does not necessarily mean that they have a deep understanding of the new digital formats that combine persuasion and entertainment. Data analysis of the interviews shows low recognition of the persuasive intent of commercial messages that are not explicitly identified as such, particularly on social networks. Data collected after minors viewing of different examples allowed researchers to conclude that standardized advertising is mainly identified by its format. Three levels of advertising processing were detected in minors: the liking of the advertisement, the affinity for the advertised product, and the ability to contrast the claims with searches for comments, forums or opinions of influencers. Recent research verified that conceptual knowledge of the persuasive intention of the advertising does not suffice for minors to interpret the message, a fact that must be taken into account when developing advertising literacy. For parents, the amount of time spent on these devices and the type of use minors make of their cellphones or the relationships they establish on them are more relevant than exposure to advertising itself.
\end{abstract}

\section{Keywords}

advertising literacy; children; hybrid advertising; mobile devices; parents perceptions; persuasive intention

\section{Issue}

This article is part of the issue "Digital Child- and Adulthood: Risks, Opportunities, and Challenges" edited by Claudia Riesmeyer (LMU Munich), Arne Freya Zillich (Film University Babelsberg KONRAD WOLF), and Thorsten Naab (German Youth Institute).

(C) 2022 by the author(s); licensee Cogitatio (Lisbon, Portugal). This article is licensed under a Creative Commons Attribution 4.0 International License (CC BY).

\section{Introduction}

Mobile phones are widely present in Western societies. The improvement of mobile internet connection has turned this personal screen into the main point of access, communication, and consumption of digital content for many users (IAB Spain, 2021), including minors. Among Chilean children aged 10 to 13 , the penetration of mobile phones is over $80 \%$ (Cabello et al., 2020; VTR, 2019).

The personal nature of mobiles and their ubiquitous presence (Ohme et al., 2020) gave rise to a relation- ship between users and cellphones that, as Beer (2012) suggests, surpasses that of a mere portal to the digital world. The massive spread of cell phone use and its impact on consumption habits and lifestyles of internet users have transformed this device into an advertising medium. In fact, according to Statista (2019), in 2022 advertising expenditure for mobile media will outpace desktop expenditure.

As mobile phone users, minors are highly exposed to advertising when using these devices. Exploratory studies (Feijoo et al., 2020) show that, through their mobile 
phones, minors spend a significant amount of time connected to platforms such as YouTube, game apps, and Instagram, in which advertising exposure has been quantified to be 14 minutes per hour, slightly higher than that of traditional media such as television.

Previous research on digital advertising addressing minors (De Jans \& Hudders, 2020; Feijoo \& Pavez, 2019; Hudders et al., 2017; López-Villafranca \& Olmedo-Salar, 2019; Ramos-Serrano \& Herrero-Diz, 2016; Rozendaal et al., 2013; Tur-Viñes et al., 2018; van Dam \& van Reijmersdal, 2019; van Reijmersdal \& Rozendaal, 2020; van Reijmersdal et al., 2012, 2017; Vanwesenbeeck et al., 2017) highlight the increasingly blurry line between entertainment and commercial content in the digital context. Other studies focusing on the consumption of advertising through mobile devices of the youngest population have also referred to and identified this blurry limit (An \& Kang, 2014; Chen et al., 2013; Terlutter \& Capella, 2013). At the same time, as is the case with the mobile phones, minors consume advertising on their own, which makes direct parental mediation more difficult (Oates et al., 2014).

In this context this article aims to research the ability of minors to understand the persuasive intentionality of the advertising they are exposed to through their mobile phones. Particular attention is paid to hybrid advertising formats, which lack intentional transparency (van Reijmersdal \& Rozendaal, 2020) and therefore, hinder the recognition of the advertising phenomenon.

\section{Children's Advertising Literacy in the Face of New Digital Formats}

Advertising literacy, also called persuasive knowledge, can be defined as the beliefs that consumers form about the motives, strategies, and tactics used in advertising (Rozendaal et al., 2013). Several theoretical models (e.g., Wright et al., 2005) establish the specific components of advertising literacy. The model proposed by Rozendaal et al. (2011), that differentiates two dimensions of advertising literacy, is used as reference in this study.

The first dimension comprises conceptual advertising literacy, which refers to the ability to recognize a commercial message and its intentions. Specifically, this dimension implies:

1. The recognition of advertising, differentiating advertising from other media content such as information or entertainment;

2. Understanding the commercial intention (that the advertising is trying to sell products);

3. Recognition of the source of advertising (who pays to insert ads);

4. Identification of the target audience (understanding the concept of targeting and audience segmentation);

5. Identification of the persuasive intention (that advertising tries to influence consumer behavior by, for example, changing attitudes towards a product);

6. Persuasive tactics (understanding that advertisers use specific tactics to persuade);

7. Capturing advertising bias (being aware of discrepancies between the advertised product and the actual one).

The second dimension is attitudinal advertising literacy, which is evaluative in nature. This dimension consists of two components: skepticism towards advertising (the tendency towards disbelief in advertising), and the level of like/dislike towards advertising.

Previous studies on advertising in traditional media, assumed that the conceptual dimension of advertising literacy was sufficient for children to filter out and process advertising messages. Nevertheless, several authors have done research on new digital advertising formats (An et al., 2014; Rozendaal et al., 2011, 2013; van Reijmersdal et al., 2017; Vanwesenbeeck et al., 2017) and their results indicate that conceptual knowledge of the persuasive intentionality of advertising is necessary but does not suffice for minors to properly process messages that exhibit non-traditional features (Livingstone \& Helsper, 2006; Rozendaal et al., 2011). This is due to the fact that when children are exposed to non-traditional advertising, they would be applying a low-effort cognitive processing, according to the model presented by Buijzen et al. (2010; PCMC model), and would fail to activate the associative network of knowledge on advertising they have developed (An et al., 2014; Mallinckrodt \& Mizerski, 2007; Rozendaal et al., 2011, 2013; van Reijmersdal et al., 2017; Vanwesenbeeck et al., 2017). The embedded, subtle, and enveloping nature of these digital ad formats increases low cognitive elaboration during exposure to them (van Reijmersdal \& Rozendaal, 2020). Moreover, children's attention is concentrated on the recreational part of the format, and therefore persuasive message processing abilities are left on the back burner (Rifon et al., 2014). The studies cited herein highlight the need to consider the attitudinal dimension of advertising literacy, which is much more effective in helping children to question and interpret advertising.

Despite the difficulties that recognizing persuasive intentionality poses, formats that present blurred boundaries between entertainment, information, and advertising are what younger audiences demand. The AdReaction study by Kantar Millward Brown (2017), revealed that younger audiences are most likely to qualify digital advertising as annoying, however their attitude becomes more positive when exposed to advertising that include rewards, use special effects, or incorporates new immersive elements. In addition, teenagers, for example, accept the presence of brands and sponsorships when it is mediated by influencers of their choice as long as the ratio between entertainment and commercial content is not disturbed (van Dam \& van Reijmersdal, 2019). 
However, the difficulty exhibited by minors in identifying the advertising intention of certain content, the possibility of airing contents unaccompanied by clear warnings given imprecise regulation and the perception of credibility with which influencers infuse commercial communications (Feijoo \& Pavez, 2019; Tur-Viñes et al., 2018), all add up to increase the risk of the current advertising context.

The need for explicit identification of the commercial interest of content is key to activate persuasive knowledge in the user (Friestad \& Wright, 1994). This has led legislators to demand adequate and clear marking of these formats as a way to protect vulnerable audiences (Boerman et al., 2012). Nonetheless, national legislations lag behind on the dynamism of the phenomenon (Sixto-García \& Álvarez Vázquez, 2020).

There is growing literature on the advertising literacy of minors in the digital context, specifically on advergaming (Hudders et al., 2017; Mallinckrodt \& Mizerski, 2007; van Reijmersdal et al., 2012; Vanwesenbeeck et al., 2017), social networks (Rozendaal et al., 2013; Zarouali et al., 2018), personalized digital advertising (van Reijmersdal et al., 2017), or influencer marketing (van Dam \& van Reijmersdal, 2019). However, empirical evidence on the advertising literacy of children with mobile phones is still missing. The use of this screen is particularly relevant among minors given its features in terms of mobility, autonomy, and universality which are incomparable to those of other means of online access (Beer, 2012).

Thus, the way in which content is consumed on mobile phone needs to be considered: Its current ubiquity allows individuals to communicate, inform, or be entertained anywhere, at any time (Ohme et al., 2020). Likewise, comparatively speaking, the perception of intrusion and invasion of the private sphere is greater via mobile than on other channels. It is considered the most personal communicational extension of human beings (Gómez-Tinoco, 2012).

In the last decade, there have been many investigations focused on the analysis of the use of mobile devices by children and young people (Mascheroni \& Ólafsson, 2014), given the high penetration the devices have had among the audience mentioned herein. Several authors have conducted exploratory studies on the consumption of advertising through mobile devices in younger children (An \& Kang, 2014; Chen et al., 2013; Terlutter \& Capella, 2013) and report a certain degree of inconsistency with respect to differentiation and categorization of persuasive messages. For example, researchers such as Chen et al. (2013) showed that age recommendations for services or content offered by apps do not cover the supervision of the inserted advertising.

Another exploratory study (Feijoo et al., 2020) revealed that this age group spends much of their time connected to mobile phones in which the level exposure to non-traditional advertising is comparatively higher than media such as television. What seems beyond doubt is that minors are using their mobile phones to access the internet as a priority and this implies a high exposure to commercial content.

It is therefore necessary to question whether children are prepared for activating their persuasion knowledge in the mobile context. Therefore, the following research questions are posed:

RQ1a: What is minors' conceptual advertising literacy with respect to advertising they receive through mobile phones, specifically in terms of (a) recognition of advertising, (b) understanding selling intent, (c) understanding persuasive intent, (d) recognition of advertising source, and (e) understanding persuasive tactics?

RQ1b: What is minors' attitudinal advertising literacy with respect to advertising they receive through mobile phones, specifically disliking it and skepticism towards it?

Furthermore, advertising literacy can be dispositional or situational (Hudders et al., 2017): Having dispositional advertising literacy involves various abilities such as (a) being in possession of the knowledge and skills about a phenomenon, and situational literacy; (b) being able to process advertisements as such; and (c) having sufficient consumer's knowledge (cognitive, moral, and affective) with regards to the advertising phenomenon. All these need to be activated when the viewer is exposed to advertising, in order for them to recognize the persuasive intention and critically reflect on the message received. To reflect on the level of correspondence between the minor's self-reported advertising literacy and their actual advertising literacy, a second research question is posed:

RQ2: Based on concrete ad mobile examples, what type of contents do children recognize as advertising?

\section{Advertising Literacy of Minors From the Perspective of Parents}

The question arises as to the extent to which access and the specific ways in which certain devices such as cellphones are used individually, hinders direct parental mediation (Oates et al., 2014). It seems pertinent to pay attention to the perceptions of parents about their children's advertising consumption through these screens.

Parental responsibilities also include mediating the relationship between minors and the content they consume, which can also be seen as an opportunity to teach them to differentiate between fiction and reality and to help them acquire healthy consumption patterns (Saraf et al., 2013). In fact, some studies suggest that parental concern may be highly relevant when it comes to acquiring certain skills (Condeza et al., 2019; Shin, 2017). However, when parents are asked about the advertising their children consume, they continue to point to television as the main source of this content 
(Oates et al., 2014). In this context, the last research question is formulated:

RQ3: What perceptions do parents have about their children's exposure to advertising on their mobile phones?

\section{Chile, a Case Study}

Chile is an interesting case study due to its high access and consumption of the internet through mobile devices (Feijoo \& Sádaba, 2021). Its 85\% internet penetration of cell phones is similar to that of other OECD countries (Subtel, 2020). The internet is mostly widely accessed through mobile devices $(84.2 \%)$, more specifically via smartphone, which account for $80 \%$ of total access (Subtel, 2020). This access pattern is replicated and accentuated by Chilean children who mainly access internet from their mobile phones, compared to other connection modes such as computers or tablets (Cabello et al., 2020; Feijoo \& García, 2019; Subtel, 2020). As is the case in other Western countries (Kabali et al., 2015), although some significant differences related to technological specificities of the equipment, influenced by the socioeconomic stratum and setting (urban vs. rural), are present (Cabello et al., 2018), the penetration of cellphones is the most socially uniform of the cited screens.

\section{Method}

\subsection{Methodological Procedures}

The objective of this research is to analyze the ability and aptitudes of minors to critically navigate the advertising they receive through their mobile phone.

To this avail, minors aged 10 to 14 and one of their parents/guardians were included in an interviewing process which incorporated semi-structured interviews. Interviews have been confirmed as an adequate instrument since most children at this age have already acquired the necessary skills to achieve successful levels of verbal exchange (Zarouali et al., 2019). This methodological approach responds to the need for new qualitative studies that can provide in-depth exploration of digital skills, including those related to critical capacity (van Deursen et al., 2016).

The interview was designed taking into consideration the following questions:

Block 1. Recognition of the advertising phenomenon: Children explained what they understood by advertising, what their opinion of advertising was, what characteristics they associated with advertising, and what level of attention they paid to advertising or what degree of realism they assigned to advertising.

Block 2. Attitude towards advertising that children were exposed via mobile phone: We tried to under- stand how children identified and processed commercial messages and their feelings during these encounters, whether advertising was liked, perceived as bothersome, if there was a willingness to watch an ad, and if it was considered as such.

Block 3. A 2 min video was played that included 17 mobile digital formats with examples from social media advertising, emailing, SMS, advertisement display from video games, and unmarked commercial content published by influencers. The aim was to confirm children's ability to identify persuasive intention.

Block 4. Parental perceptions: What do parents know and think about the role of their children as recipients of advertising.

Qualitative data were obtained by means of a thematic analysis using NVivo (Boyatzis, 1995). The research questions and the topics included in the interview script guided which coding categories were established. Given the researchers' long-standing engagement with the topic, both authors participated in the coding process in order to improve the quality of the ensuing interpretation of the analyzed material.

\subsection{Sample}

Twenty homes were visited between June and August 2019, all located in the metropolitan area of Santiago de Chile to interview one child and one of their parents or guardian per household. As for the minors, 12 were girls and eight were boys; 10 were aged 10 to 12 years old, and the other 10 children were aged 13 or 14 years old; 11 had their own mobile and the rest (nine) used their parents' mobile. As for adults, mothers were generally interviewed (18), with only two exceptions in which a father and an older sister (the child's guardian) were interviewed. Regarding the socioeconomic level of the families, 10 qualify as belonging to level C1 (high), 6 to C2-C3 (middle), and 4 to D (low).

The homes sampled had participated in a previous phase of the research project to which this study belongs, in which face-to-face surveys were applied in 501 households to both one minor and one parent/guardian following a probabilistic design by areas/macrozones. A social studies company was in charge of the field work (Feedback S.L) who constructed their network of interviewers with previous experience in research studies with minors available to the authors. Households in which a minor aged 10 to 14 lived was randomly selected within each macrozone in the quantitative process. In those cases in which there was more than one individual who met the selection characteristics, the one who had his birthday closest to the day of the survey was selected. It is from this sampling frame that 20 families, who agreed to participate in the project, were selected. The children should meet the age and gender criteria 
defined for this qualitative stage, in addition to having telephone ownership, since the navigation registered on the device directly influences the type of advertising the user receives. It is important to clarify that in this second phase an attempt was made to access all kinds of family profiles, as had been achieved in the quantitative process, however, families of well-off levels were more collaborative, hence in the interviews there is a greater representation of the groups C1 while other socioeconomic groups are not equally represented.

During the interview, the interviewer first explained the essence of the interview to the parent or adult responsible for the household, who had to issue a signed consent for the minor to participate in this stage of the study. Next, the consent of the minor himself had to be obtained. In a neutral area of the home (kitchen or living room) the interview was completed with a maximum duration of 20-25 min with the aim of preserving the child's attention. An attempt was made to ensure that guardians were not present during the interview to prevent any possible interference with the responses of minors. Finally, after interviewing children, interviews finished with a last set of questions addressed to adults regarding their perceptions of the relationship of minors with advertising on mobile phones.

All documents had been previously reviewed and validated by the Ethics Committee of the university to which the research project is linked (University of Los Andes).

\section{Results}

\subsection{Conceptual Advertising Literacy}

The following elements of conceptual advertising literacy (Rozendaal et al., 2011) were expressed by children: (a) recognition of advertising; (b) understanding of selling intent; (c) recognition of advertising source; (d) identification of the target audience; (e) understanding of persuasive intent; (f) understanding of persuasive tactics; and (g) the advertising bias, but in variable degrees depending on their experience as consumers and mobile phone ownership.

Minors are aware that advertising "sells things": "It is something that companies use to get people's attention and make them buy their product or do get people to do whatever the company aims at them doing" (I11-girl, 10-to-12 years old, parental smartphone). It was interesting to see that, although at first, they were asked about the phenomenon in general, they spontaneously associated advertising with the digital context, mobile phones, and social networks. Other advertising media, such as television or advertising present in their milieu, appeared in conversations, but in a suggested way; others such as print media or radio were not mentioned: "Advertising is like a way of informing using images and other means during short periods of time when you are looking for something or they appear in all apps or networks" (13-boy, 13-to-14 years old, own smartphone).
Regarding the recognition of the source of advertising, a certain degree of confusion was apparent, caused by the digital context and the normalization of social networks. Thus, while the majority referred to companies or brands as the main sources, some of the younger children connected the source of advertising to people: "[Advertising is] what you get on the networks, what people offer you through cell phones" (I14-girl, 10-to-12 years old, own smartphone).

In this study, it was found that minors in general understand that ads seek to get viewers interested in wanting to have the products displayed, "that they want to convince you to buy the product, to go to the place they are promoting" (I11-girl, 13-to-14 years old, own smartphone). Children who declared having experience as consumers and who own a mobile phone tended to be more aware of the purpose of advertising and were able to reason that the ads, and certain content launched by influencers, was aimed at attracting user attention with the goal of selling:

They convince the person, for example, that the application is good, that this product is good, and they include sales so that the person buys it and more people buy it. And in the end, they get their way, because if more people buy it, they earn more. (I16-boy, 10-to-12 years old, own smartphone)

Indeed, influencers have become recurring intermediaries between brands and young consumers in the digital context. Therefore, those who identify the persuasive intentionality of this commercial relationship, deem it as normal and appropriate. Moreover, they believe it contributes to getting to know brands and products in a "more entertaining way":

I like that Mis Pastelitos [a YouTuber] tells me what flour they choose to use, for example, or the fact a pastry bag number six is needed; then you have to go and buy a number six pastry bag and make the cupcake in question. Perfect. In other words, these are things that help me resolve my questions. (I13-girl, 13-14 years old, parents' mobile)

Some minors reflect on the addressee of the ads. Minors are aware that certain messages to which they are exposed are not addressed to them but to a different target audience, their parents, for instance. This is particularly true when minors access the internet using their parents' devices.

Spontaneously in the conversation, the children alluded to certain tactics that are directly related to advertising, particularly repetition, since it directly influences their attitude towards these types of messages: "Suddenly they go a bit over the top, because they kind of always show, show and show. For example, on YouTube or in a video you see ten advertisements, and the same ones" (11-girl, 10-to-12, parental smartphone). 
Moreover, some of the advertising resources detected by children allow them to identify that they are being exposed to advertising: "I realize that it is advertising because they make a saying, like Soprole [dairy brand], which is 'Soprole,' healthy and delicious" (I12-girl, 10-to-12 years old, parental smartphone). Other resources that they associate with the advertising messages are gifts, promotions, rewards, or eye-catching elements: "First when you download [a game] it's free, but then some things you have to pay for. The first day they give you them for free and then you have to pay" (12-boy, 10-to-12 years old, parents smartphone). Unlike other media, such as television, where they consider the display of advertisements as "orderly," advertisements, on mobile phones they pop up unexpectedly which is perceived by minors as if advertising is continually "going to their encounter." However, in they didn't relate this situation to the personalization of digital advertising. Interruption is another element that most of the interviewees associate with mobile advertising, which they say makes them miss out on other input that may be of greater interest to them.

There were few minors interviewed who reflected on the final intention of these tactics. Only two of them (males between 13 and 14 years old with their own mobile) spontaneously commented that advertising is not objective, that it tends to be unrealistic and exaggerated: "There are some advertisements I can't believe, such as those that say that life can be easier by buying some things, but later when you buy them, they are easily wrecked" (I3-boy, 13-to-14 years old, own smartphone).

\subsection{Attitudinal Advertising Literacy}

To measure the attitudinal dimension of advertising literacy, attention was paid to answers to the like/dislike generated by mobile advertising and the degree of skepticism with which they face it. Minors do not dislike mobile advertising as long as they have control over it, that is, when they, as users, can decide to view the ad or not, and when ads provide some added value, either in the form of entertainment or a reward, especially in gaming apps, in which they gladly invest their attention in exchange for benefits in the game:

Suddenly advertising gives you a chance to test a game, I do like that. Or when you can turn your phone into a $360^{\circ}$ phone, and by turning your phone it shows your what is around you, that does attract attention. (I1-girl, 10-to-12 years old, parental smartphone)

For minors, mobile advertising as content is interesting because it can provide new information, although children are unanimously bothered by the ensuing interruption in what they were doing, in addition to the fact advertising is repetitive and excessive. Hence their main reaction is to omit advertising instantly: "I don't care if advertising appears, but I do want it to appear between songs, not in the middle of the song" (I5-girl, 13-to-14 years old, own smartphone).

When analyzing children's responses, we identified three arguments they used to discriminate the advertisements that interest them from those that do not. The most widely used criteria is their own taste and appetite: A significant percentage of children identify advertising based on whether they like it or not, which directly depends on the degree of entertainment advertising provides them. Others apply a second criteria, that relates to their affinity with the advertised product: "My ideal advertisement would be something like toys or things like that, chocolates, but not cars, or wines, or beers, or anything like that" (I14-girl, 10-to-12 years old, parental smartphone). A third, smaller percentage of the sample demonstrated that they contrast the arguments asserted by advertising with their own searches for information:

If I am interested in buying [a cell phone], then I would look further to see if it is really necessary, if it is good, if it suits me or I should wait for a different one, if the price is really high for what that cell phone really offers, things like that. (I16-boy, 10-to-12 years old, own smartphone)

This more critical attitude is present among minors who have their own device and who acquired previous experiences as consumers:

I don't believe advertising when it shows something that is very spectacular because of the image, perhaps in person, in real life, it is not like that. I don't know, for example, the other day I saw a tracksuit that looked very cute, but its fabric, when I later bought it was not like it was in the advertisement. (I6-girl, 13-to-14 years old, own smartphone)

Credulity during the discrimination process is present, more so among younger profiles, with a rather relative questioning of advertising bias: "I trust advertising because, if it were bad advertising, companies would probably not be able to air it" (I17-boy, 10-to-12 years old, parental smartphone).

On the other hand, only one minor of the 20 interviewees alluded to the influence of their parents' opinion in their processing of the advertisements encountered.

\subsection{Situational Recognition}

In order to analyze the level of advertising literacy among minors from a situational approach (Zarouali et al., 2019), 17 advertisements launched by mobile phones were displayed to children. These ads included displays in video games, as well as standard formats used in Instagram, Facebook, YouTube, SMS, and emailing formats, in combination with examples of hybrid commercial content (Feijoo et al., 2021). 
Exposure to specific cases showed that minors tended to recognize standard format advertisements: "When I get an ad that interrupts what I'm doing at the most interesting point, I wait until it ends or until it says skip the ad" (19-girl, 10-to-12 years old, own smartphone). The fact that children can identify commercial messages by some type of signal enables them to be aware of their presence, meaning that identification is not a result of critical processing:

Every now and then an image appears [on Instagram] if you click it, you are taken directly to the store. For example, you can click on the Nike shirt and a tick appears at the bottom, something resembling a bag. At first, I didn't know what it was, but then you click on the photo and the price of the shirt and the store where it sold will appear. (I1-girl, 10-to-12 years old, parental smartphone)

Consequently, examples that did not display any kind of warning were not singled out as advertising by participants:

[The influencer wearing a Nike t-shirt] is not using the method of pushing people to do something, as he/she does not provide information on it nor tell you to "go, go, go" It is simply a normal photo, like me wearing clothes, for example. (I11-girl, 13-to-14 years old, own smartphone)

Indeed, the interest-mediated relationship between brands and influencers was detected by five of the 20 interviewees, all of them minors aged 13 or 14 years old:

Influencers are paid, they must say "hey, look, we pay you X and you have McDonald's appear," and the influencer must say "Yeah, no problem." That is typical among that YouTubers who say "This video is sponsored by X," and they wear X clothes to promote them. (I13-girl, 13-to-14 years old, parental smartphone)

Minors don't question this practice, nor the fact that YouTubers are self-promoting themselves: "It doesn't bother me, if they are famous, they will sell their own things, such as clothes and all that kind of stuff" (I20-girl, 13-to-14 years old, own smartphone). It was also revealed that minors related varying exposure to advertising depending on the platform. For example, minors considered that YouTube and video games were saturated with ads, and reported less advertising pressure on Instagram and TikTok.

\subsection{Parents' Position on Their Children's Advertising Exposure}

Regarding parental opinion on the exposure to advertising their children encounter when browsing on mobile phones, the greatest level of agreement is in the high pressure of advertising: "There is nothing on the internet that is not invaded by advertising" (mother, 116-boy, 10to-12 years old, own smartphone). However, they are not concerned about this high presence of commercial content and consider that it does not pose a risk to their children. There are two main reasons that parents give for being calm. The first one is their children's age or attitude towards advertising, "it is rare that she sees much advertising, she always chooses to avoid it. She clicks it off at once. She doesn't pay attention to it" (mother, 19-girl, 10-to-12 years old, own smartphone). As it could be seen, parents' perception favors their children's age as one of the most important containment barriers to being worried about the amount and the type of advertising they consume through their mobile phones.

The second one is precisely the fact that advertising is personalized based on the content children consume (games, hobbies), which, in their opinion, defines the type of advertising they receive and limits it to these interests: “In general, I think children don't receive harmful advertising, in general it's merely on video games, and we have those under control" (mother, 17-boy, 10-to-12 years old, own smartphone). Also, the fact that much of this advertising is also shown on television validates it as not harmful to minors.

It is hard to find more elaborate visions on the relationship between minors and advertising among parents. Their perception of online risks lies, fundamentally, in the consumption of certain content or in the possibility of being exposed to other dangerous situations. They also tend to minimize their own role in this context, something that, according to previous research (Condeza et al., 2019; Shin, 2017) could be a lot more relevant than the children's age to acquire the skills necessary to adequately cope with this content.

\section{Discussion}

This study provides additional evidence which verifies that the conceptual knowledge of advertising is not enough to be able to identify it in the digital environment, as advanced by Livingstone and Helsper (2006), as well as Rozendaal et al. (2011). Minors are aware of the presence of advertising in the digital environment and they acknowledge its excessive presence, a notion unanimously shared by their parents. This study provides more evidence supporting the idea that when children encounter hybrid content, they respond with low-effort cognitive processing (An et al., 2014; Mallinckrodt \& Mizerski, 2007; Rozendaal et al., 2011, 2013; van Reijmersdal et al., 2017; Vanwesenbeeck et al., 2017). The role played by the presence of formal aspects in advertisements which help children identify advertisements becomes particularly relevant, as indicated by $A n$ et al. (2014). Thus, participants in this study tend to distinguish the advertising they see in their cellphones from other types of messages not by the content, but by the form it takes, which is to say that 
recognition derives from technical aspects, not critical processing. However, when these external signals are not present, minors do not classify the content as advertising. Format brings along trust and thus intentionality remains unquestioned. This would explain why the majority of those interviewed did not question whether the recommendations provided by the influencers they follow on social networks may be promoted content.

Furthermore, there seems to be a certain transfer of positive sentiment towards advertising when ads pop up in an entertainment context (Mallinckrodt \& Mizerski, 2007; van Reijmersdal et al., 2012). Also contributing to this positive feeling towards advertising is the fact that ads adjust to their tastes and preferences, as pointed out by van Reijmersdal et al. (2017). Advertising only becomes bothersome when children feel they cannot control its presence, it is perceived as boring or it interrupts their browsing experience.

This study also provides evidence in the direction that mobile ownership and degree of expertise in the digital environment are related to more critical attitudes towards advertising. Thus, the extent to which these two factors are related to the child's age, the relevance of the aforementioned factors would go in the same direction of what has been proposed by Chu et al. (2014) and Hudders et al. (2017) regarding greater cognitive development among older minors.

For the new generations, the mobile phone has become the main advertising medium, ahead of other classic media such as television. The fact that mobile screens are mainly for personal use seems to generate low tolerance levels towards interruption, repetition, or content beyond their immediate interests. Minors, however, do not seem to connect this rather negative attitude to advertising itself. They seem to associate negativity to how saturated of advertisement the media are and to their lack of control (and ensuing frustration) over unsolicited advertising. Now, if advertising provides added value in the form of tangible compensation (promotions, discounts, rewards in games) or in the form of entertainment, the perception of minors on mobile ads improves. Therefore, advertising forms such as content marketing and commercial content created by influencers turn out to be the persuasive communication that best captures minors attention and intention.

This presents a great dilemma because it is the audience itself that demands formats with blurred boundaries between advertising, entertainment, and information on mobile phones. This fact shows the need for those responsible for child development to reinforce children's advertising literacy with regard to the use of mobiles. This reinforcement stems from critical thinking, an ability that has been qualified as one of the key digital skills of the 21st century (van Laar, 2019).

The challenges that these results pose for advertising literacy are clear: Minors have knowledge that allows them to identify advertising as long as it is marked or includes resources with which they are familiar (repeti- tion, presence of certain icons, etc). However, the ability to identify advertising is hindered, particularly among those with less browsing expertise or when advertising is integrated within other content. In addition, recognition does not imply the activation of critical thinking, given that if advertising is perceived as an entertaining element (something particularly demanded from mobile advertising by the youngest), acceptance sets in and limits the cognitive resources they have to processing the message.

Parents, as a filter in their children's advertising literacy, seem concerned about the amount of advertising to which their children are exposed in a generic way. However, they view message advertising customization as some type of protective effect and think that their children's age makes them resistant to possible commercial interests for products out of other children's age range. According to the literature, parents consider television to be a main source of advertising consumption by their children's (Oates et al., 2014) and also seem to think that their children's age makes them only vaguely interested in advertising content. Thus, parents do not seem to be aware that the acquisition of healthy advertising consumption habits by minors can depend much more on parental intervention than on their children's age (Condeza et al., 2019; Shin, 2017).

\section{Conclusions}

This study once again highlights what many researchers have been saying for some time: the need to abandon arguments solely based on the amount of time children spend in front of screens, and focus the debate on qualitative questions, taking into account variables such as content, context, and connections (Livingstone, 2018). Messages to parents need to be improved, as parents try to enforce rules based on the control of the amount of time spent on screens, an area that is particularly difficult to restrain given the ubiquity of technology.

In a digital environment in which hybrid content abounds, signaling of commercial content is a must but does not suffice: More research is needed to learn how to make everyone aware of the need to develop advertising literacy through which the use of critical thinking can be ensured. This becomes crucial at a time in which children are interacting with a screen that can be accessed anywhere, anytime, and in a very personal and personalized way with whatever filter they may have been able to individually establish.

\section{Acknowledgments}

This work was supported by the Ministry of Science and Innovation of the Government of Spain under I+D+i Project ref. PID2020-116841RA-I00. Research also funded by the Research Plan of the International University of La Rioja (UNIR), 2020-2022 biennium. We also wish to thank Angela Gearhart for her translation of the original manuscript into English. 


\section{Conflict of Interests}

The authors declare no conflict of interests.

\section{References}

An, S., Jin, H. S., \& Park, E. H. (2014). Children's advertising literacy for advergames: Perception of the game as advertising. Journal of Advertising, 43(1), 63-72. https://doi.org/10.1080/00913367.2013.795123

An, S., \& Kang, H. (2014). Advertising or games? Advergames on the internet gaming sites targeting children. International Journal of Advertising, 33(3), 509-532. https://doi.org/10.2501/IJA-33-3-509-532

Beer, D. (2012). The comfort of mobile media: Uncovering personal attachments with everyday devices. Convergence, 18(4), 361-367. https://doi.org/10.1177/ 1354856512449571

Boerman, S. C., van Reijmersdal, E. A., \& Neijens, P. C. (2012). Sponsorship disclosure: Effects of duration on persuasion knowledge and brand responses. Journal of Communication, 62(6), 1047-1064. https://doi. org/10.1111/j.1460-2466.2012.01677.x

Boyatzis, R. (1995). Transforming qualitative information: Analysis and code development. SAGE.

Buijzen, M., van Reijmersdal, E. A., \& Owen, L. H. (2010). Introducing the PCMC model: An investigative framework for young people's processing of commercialized media content. Communication Theory, 20(4), 427-450. https://doi.org/10.1111/j.14682885.2010.01370.x

Cabello, P., Claro, M., Lazcano, D., \& Antezana, L. (2018). La inclusión digital de niños y adolescentes chilenos desde la perspectiva de usos y habilidades [The digital inclusion of Chilean children and adolescents from the perspective of uses and skills]. In E. Jiménez, M. Garmendia, \& M. Á. Casado (Eds.), Entre selfies y Whatsapps. Oportunidades y riesgos para la infancia y la adolescencia conectada [Between selfies and Whatsapps. Opportunities and risks for connected childhood and adolescence] (pp. 259-278). Gedisa.

Cabello, P., Claro, M., Rojas, R., \& Trucco, M. (2020). Children's and adolescents" digital access in Chile: The role of digital access modalities in digital uses and skills. Journal of Children and Media, 15(2), 183-201. https://doi.org/10.1080/17482798.2020.1744176

Chen, Y., Zhu, S., Xu, H., \& Zhou, Y. (2013). Children's exposure to mobile in-app advertising: An analysis of content appropriateness. In Proceedings of the SocialCom 2013, International Conference on Social Computing (pp. 196-203). Institute of Electrical and Electronics Engineers. https://doi:10.1109/ SocialCom.2013.36

Chu, M. T., Blades, M., \& Herbert, J. (2014). The development of children's scepticism about advertising. In M. Blades, C. Oates, F. Blumberg, \& B. Gunter (Eds.), Advertising to children: New directions, new media (pp. 38-49). Springer. https://doi.org/ $10.1057 / 9781137313256$

Condeza, R., Herrada-Hidalgo, N., \& Barros-Friz, C. (2019). Nuevos roles parentales de mediación: Percepciones de los padres sobre la relación de sus hijos con múltiples pantallas [New parental mediation roles: Parents" perceptions of their children's relationship with multiple screens]. El Profesional de la Información, 28(4), Article e280402. https://doi.org/10.3145/epi. 2019.jul.02

De Jans, S., \& Hudders, L. (2020). Disclosure of vlog advertising targeted to children. Journal of Interactive Marketing, 52, 1-19. https://doi.org/10.1016/ j.intmar.2020.03.003

Feijoo, B., Bugueño, S., Sádaba, C., \& García-González, A. (2021). Parents' and children's perception on social media advertising. Comunicar, 67, 99-109. https:// doi.org/10.3916/C67-2021-08

Feijoo, B., \& García, A. (2019). Actitud del menor ante la publicidad que recibe a través de los dispositivos móviles [Children attitude faced with the advertising they receive through their mobile devices]. adComunica, 18, 199-218. http://dx.doi.org/10.6035/21740992.2019.18.10

Feijoo, B., \& Pavez, I. (2019). Contenido audiovisual con intención publicitaria en vídeos infantiles en YouTube: El caso de la serie Soy Luna [Audiovisual content with advertising intention in children's videos on YouTube: the case of the Soy Luna series]. Communication \& Society, 32(1), 313-331 http://dx. doi.org/10.15581/003.32.1.313-331

Feijoo, B., \& Sádaba, C. (2021). Is my kid that naive? Parents' perceptions of their children's attitudes towards advertising on smartphones in Chile. Journal of Children and Media, 15(4), 476-491. https:// doi.org/10.1080/17482798.2020.1866626

Feijoo, B., Sádaba, C., \& Bugueño, S. (2020). Anuncios entre vídeos, juegos y fotos. Impacto publicitario que recibe el menor a través del teléfono móvil [Ads in videos, games, and photos: Impact of advertising received by children through mobile phones]. Profesional de la Información, 29, Article e290630. https:// doi.org/10.3145/epi.2020.nov.30

Friestad, M., \& Wright, P. (1994). The persuasion knowledge model: How people cope with persuasion attempts. Journal of Consumer Research, 21(1), 1-31. https://doi.org/10.1086/209380

Gómez-Tinoco, A. (2012). El mobile marketing como estrategia de comunicación [Mobile marketing as a communication strategy]. Revista ICONO 14, 8(1), 238-260. https://doi.org/10.7195/ri14.v8i1.292

Hudders, L., De Pauw, P., Cauberghe, V., Panic, K., Zarouali, B., \& Rozendaal, E. (2017). Shedding new light on how advertising literacy can affect children's processing of embedded advertising formats: A future research agenda. Journal of Advertising, 46(2), 333-349. https://doi.org/10.1080/00913367. 2016.1269303 
IAB Spain. (2021). Estudio mobile \& conectividad inteligente 2021 [Mobile \& smart connectivity study 2021]. https://iabspain.es/estudio/estudio-mobileconectividad-inteligente-2021

Kabali, H., Irigoyen, M., Nunez-Davis, R., Budacki, J., Mohanty, S., Leister, K., \& Bonner, R. (2015). Exposure and use of mobile media devices by young children. Pediatrics, 136(6), 1044-1050. https://doi.org/ 10.1542/peds.2015-2151

Kantar Millward Brown. (2017). AdReaction: Engaging Gen $X, Y$ and Z. http://www.millwardbrown.com/ adreaction/genxyz

Livingstone, S. (2018, October 10). Six myths about children in the digital age. LSE. https://blogs.Ise.ac.uk/ parenting4digitalfuture/2018/10/10/six-mythsabout-children-in-the-digital-age

Livingstone, S., \& Helsper, E. J. (2006). Does advertising literacy mediate the effects of advertising on children? A critical examination of two linked research literatures in relation to obesity and food choice. Journal of Communication, 56(3), 560-584. https://doi. org/10.1111/j.1460-2466.2006.00301.x

López-Villafranca, P., \& Olmedo-Salar, S. (2019). Menores en YouTube, ¿̇ocio o negocio? Análisis de casos en España y EUA [Minors on YouTube, entertainment or business? Analysis of cases in Spain and the USA]. Profesional de la Información, 28(5), Article e280520. https://doi.org/10.3145/epi.2019.sep.20

Mallinckrodt, V., \& Mizerski, D. (2007). The effects of playing an advergame on young children's perceptions, preferences, and requests. Journal of Advertising, 36(2), 87-100. https://doi.org/10.2753/ JOA0091-3367360206

Mascheroni, G., \& Ólafsson, K. (2014). Net children go mobile: Risks and opportunities (2nd ed.). Educatt. https://netchildrengomobile.eu/ncgm/wp-content/ uploads/2013/07/DEF_NCGM_SecondEdition_ Report.pdf

Oates, C., Newman, N., \& Tziortzi, A. (2014). Parent's beliefs about, and attitudes towards, marketing to children. In M. Blades, C. Oates, F. Blumberg, \& B. Gunter (Eds.), Advertising to children: New directions, new media (pp. 115-136). Springer. https://doi.org/ 10.1057/9781137313256

Ohme, J., Vanden-Abeele, M. M., van Gaeveren, K., Durnez, W., \& De Marez, L. (2020). Staying informed and bridging "social distance": Smartphone news use and mobile messaging behaviors of flemish adults during the first weeks of the Covid-19 pandemic. Socius, 6, 1-14. https://doi.org/10.1177/ 2378023120950190

Ramos-Serrano, M., \& Herrero-Diz, P. (2016). Unboxing and brands: Youtubers phenomenon through the case study of EvanTubeHD. Prisma Social: Revista de Ciencias Sociales, 1, 90-120. https://revista prismasocial.es/article/view/1315

Rifon, N. J., Taylor Quilliam, E., Paek, H. J., Weatherspoon, L. J., Kim, S. K., \& Smreker, K. C. (2014). Age- dependent effects of food advergame brand integration and interactivity. International Journal of Advertising, 33(3), 475-508. https://doi.org/10.2501/IJA33-3-475-508

Rozendaal, E., Lapierre, M. A., van Reijmersdal, E. A., \& Buijzen, M. (2011). Reconsidering advertising literacy as a defense against advertising effects. Media Psychology, 14(3), 333-354. https://doi.org/10.1080/ 15213269.2011.620540

Rozendaal, E., Slot, N., van Reijmersdal, E. A., \& Buijzen, M. (2013). Children's responses to advertising in social games. Journal of Advertising, 42(2/3), 142-154. http://dx.doi.org/10.1080/00913367. 2013.774588

Saraf, V., Jain, N. C., \& Singhai, M. (2013). Children and parents' interest in TV advertisements: Elucidating the persuasive intent of advertisements. Indian Journal of Marketing, 43(7), 30-43, https://doi.org/ 10.17010/ijom/2013/v43/i7/34016

Shin, W. (2017). Active mediation of television, internet and mobile advertising. Young Consumers, 18(4), 378-392. https://doi.org/10.1108/YC-06-201700700

Sixto-García, J., \& Álvarez Vázquez, A. (2020). Influencers en Instagram y publicidad engañosa: La necesidad de regular y autorregular [Influencers on Instagram and misleading advertising: The need to regulate and self-regulate]. Estudios Sobre el Mensaje Periodístico, 26(4), 1611-1622. https://doi.org/10.5209/ esmp.66921

Statista. (2019). Mobile set to outpace desktop ad spending by 2022. https://www.statista.com/chart/ 19792/global-mobile-ad-spending-distribution-byplatform

Subtel. (2020). Informe semestral del sector telecomunicaciones-Primer semestre 2020 [Telecommunications sector semiannual reportFirst half 2020]. https://www.subtel.gob.cl/estudiosy-estadisticas/informes-sectoriales-anuales

Terlutter, R., \& Capella, M. L. (2013). The gamification of advertising: Analysis and research directions of in-game advertising, advergames, and advertising in social network games. Journal of Advertising, 42(2/3), 95-112. https://doi.org/10.1080/00913367. 2013.774610

Tur-Viñes, V., Núñez Gómez, P., \& González-Río, M. J. (2018). Menores influyentes en YouTube. Un espacio para la responsabilidad [Kid influencers on YouTube. A space for responsibility]. Revista Latina de Comunicación Social, 73, 1211-1230. https://doi.org/ 10.4185/RLCS-2018-1303

van Dam, S., \& van Reijmersdal, E. A. (2019). Insights in adolescents' advertising literacy, perceptions and responses regarding sponsored influencer videos and disclosures. Cyberpsychology: Journal of Psychosocial Research on Cyberspace, 13(2), Article 2. http:// dx.doi.org/10.5817/CP2019-2-2

van Deursen, A. J. A. M., Helsper, E. J., \& Eynon, R. (2016). 
Development and validation of the Internet Skills Scale (ISS). Information, Communication and Society, 19(6), 804-823. https://doi.org/10.1080/1369118X. 2015.1078834

van Laar, E. (2019). What are E-ssential skills? A multimethod approach to 21st-century digital skills within the creative industries. University of Twente. https://research.utwente.nl/en/publications/whatare-e-ssential-skills-a-multimethod-approach-to21st-century

van Reijmersdal, E. A., \& Rozendaal, E. (2020). Transparency of digital native and embedded advertising: Opportunities and challenges for regulation and education. Communications, 45(3), 378-388. https://doi. org/10.1515/commun-2019-0120

van Reijmersdal, E. A., Rozendaal, E., \& Buijzen, M. (2012). Effects of prominence, involvement, and persuasion knowledge on children's cognitive and affective responses to advergames. Journal of Interactive Marketing, 26(1), 33-42. https://doi.org/10.1016/ j.intmar.2011.04.005

van Reijmersdal, E. A., Rozendaal, E., Smink, N., Van Noort, G., \& Buijzen, M. (2017). Processes and effects of targeted online advertising among children. International Journal of Advertising, 36(3), 396-414. https://doi.org/10.1080/02650487.2016.1196904

Vanwesenbeeck, I., Walrave, M., \& Ponnet, K. (2017).
Children and advergames: The role of product involvement, prior brand attitude, persuasion knowledge and game attitude in purchase intentions and changing attitudes. International Journal of Advertising, 36(4), 520-541. https://doi.org/10.1080/ 02650487.2016 .1176637

VTR. (2019). Digital radiography 2019. https:// vtrconvivedigital.com/CS/vivedigital/pdf/ Analisis_Radiografia_Digital_VTR\%202019.pdf

Wright, P., Friestad, M., \& Boush, D. M. (2005). The development of marketplace persuasion knowledge in children, adolescents, and young adults. Journal of Public Policy and Marketing, 24(2), 222-233. http:// www.jstor.org/stable/30000661

Zarouali, B., De Pauw, P., Ponnet, K., Walrave, M., Poels, K., Cauberghe, V., \& Hudders, L. (2019). Considering children's advertising literacy from a methodological point of view: Past practices and future recommendations. Journal of Current Issues \& Research in Advertising, 40(2), 196-213. https://doi.org/ 10.1080/10641734.2018.1503109

Zarouali, B., Poels, K., Walrave, M., \& Ponnet, K. (2018). "You talking to me?" The influence of peer communication on adolescents" persuasion knowledge and attitude towards social advertisements. Behaviour \& Information Technology, 37, 502-516. https://doi. org/10.1080/0144929X.2018.1458903

\section{About the Authors}

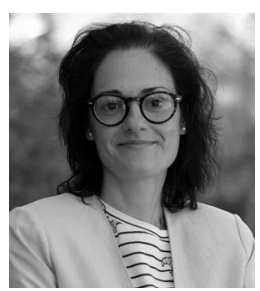

Beatriz Feijoo (PhD) is an associate professor of advertising and marketing at the School of Business and Communication, International University of La Rioja (Spain). Her research focuses on communication and children, the use of screens in new generations, and more recently on the relationship between minors and advertising through the mobile devices. She is also the principal investigator of funded research projects (Fondecyt N¹1170336-Chile; I+D+i Project-Spain ref. PID2020-116841RAI00; PENSACRIGITAL-UNIR) on communication, new media, childhood, and adolescence.

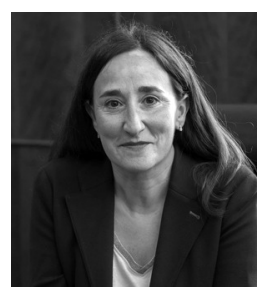

Charo Sádaba (PhD) is an associate professor of advertising and marketing at the School of Communication, University of Navarra (Spain). Her research has been focused on the impact of digitalization on children and teenagers, their behavior, attitudes and opinions towards technology, particularly in Spain and Latin American countries. More recently she has started a project on the impact of technology in emerging adulthood. 